\title{
VKORC1 Gene
}

National Cancer Institute

\section{Source}

National Cancer Institute. VKORC1 Gene. NCI Thesaurus. Code C48680.

This gene is involved in blood clotting via the enzymatic activation of Vitamin $\mathrm{K}$. 